\title{
Genetic Variability, Heritability and Genetic Advance Estimates in Quality Protein Maize (Zea mays L.)
}

\author{
K. Sukumar*, V. Hemalatha, V. Narsimha Reddy, \\ S. Narender Reddy and D. Srinivasa Chary
}

Professor Jayashankar Telangana State Agricultural University, Telangana, India

*Corresponding author

\begin{tabular}{|l|}
\hline Ke y w o r d s \\
QPM, Variation, \\
heritability and \\
Genetic advance \\
\hline Article Info \\
\hline $\begin{array}{l}\text { Accepted: } \\
\text { 20 July 2020 } \\
\text { Available Online: } \\
\text { 10 August } 2020\end{array}$ \\
\hline
\end{tabular}

Keywords

QPM, Variation,

heritability and

Genetic advance

Article Info

Accepted:

20 July 2020

Available Online

\section{A B S T R A C T}

PCV values were slightly higher than GCV values for all the characters under the study. A perusal of genetic parameters viz., phenotypic and genotypic coefficients of variation revealed less influence of environment on the characters under study. Therefore, response to direct selection may be effective in improving these traits. Majority of the characters exhibited higher heritability values in which ear height and ear girth recorded the highest values (99\%) followed by days to $50 \%$ anthesis (98\%), days to $50 \%$ silking (97\%) and number of kernels per row (97\%), ear length $(95.1 \%)$, grain yield $(93.9 \%)$, number of kernel rows per ear $(92.8 \%)$, crude protein $(85 \%)$, days to maturity $(83.7 \%)$ and lysine $(63 \%)$. High heritability indicated that these characters were least effected by the environment and selection is effective for the improvement.

\section{Introduction}

Maize is an important staple food crop next to wheat and rice. It is considered as queen of cereals due to its wider adaptability and production potential. However, the has been experiencing many biotic and abiotic stresses thereby decline in the yield levels and hence availability of variability in the population provides a strong base for selection of elite lines for various purposed and hence determination of genetic variability is the prime requisite for the purpose. Genetic variability for biometric traits is the key component of breeding programmes for broadening the genetic base of any crop. Genetic diversity constitutes the base material for plant improvement and provides protection against genetic vulnerability to various stresses (Wang and $\mathrm{Lu}, 2006$ ). The parameters like genotypic and phenotypic coefficients of variation (GCV and PCV) will be useful to understand the extent of variability present in the material. Heritability 
and Genetic advance (GA) play a crucial role during the selection process depending upon the extent of variability (Bilgin et al., 2010). Heritability (both in broad \& narrow sense) is of interest to plant breeders primarily as a measure of the value of selection for particular trait in various types of progenies and as an index of transmissibility. Heritability in broad sense is defined as a ratio of the total heritable variance (genotypic variance) to total phenotypic variance (Johnson et al., 1955). The necessity for partitioning the phenotypic variability into heritable and non-heritable components was suggested by Panse (1957), because highly heritable characters showed the least influence for environmental fluctuations. The heritability estimate is the important component of predicting genetic advance.

\section{Materials and Methods}

A total of thirty one Quality Protein Maize (QPM) genotypes obtained from Maize Research Centre, Agricultural Research Institute, Rajendranagar, Hyderabad were planted in Randomized Block Design with three replications during kharif, 2014 at College Farm, College of Agriculture, Rajendranagar, Hyderabad. The data was collected on characters viz., days to 50 per cent anthesis, days to 50 per cent silking, Anthesis silking interval(ASI), days to maturity, plant height $(\mathrm{cm})$, ear height $(\mathrm{cm})$, ear length $(\mathrm{cm})$, ear girth $(\mathrm{cm})$, number of kernel rows per ear, number of kernels per row, grain yield (g/plant),100 kernel weight (g), shelling percentage, crude protein (\%), lysine content $(\%)$ and tryptophan content (\%). Analysis of variance was computed based on Randomized Block Design for each of the character separately as per standard statistical procedure (Panse and Sukhatme, 1985). The test of significance was carried out by referring to ' $F$ ' table values given by Fisher and Yates (1967). For statistical analysis, windostat version 9.1 software package was used. The model of ANOVA used is presented below.

The analysis of variance for each character was carried out by using the method described by Panse and Sukhatme (1985).

The genotypic and phenotypic variance was calculated as per the formulae given by Burton and Devane (1953).

Genotypic variance $\left(\sigma^{2} \mathrm{~g}\right)$

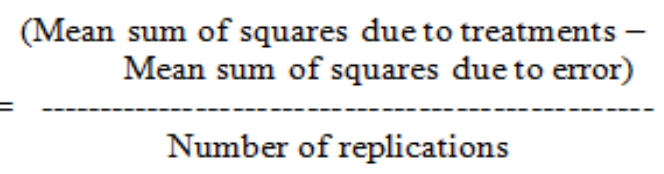

Phenotypic variance $\left(\sigma^{2} p\right)=\left(\sigma^{2} g\right)+\left(\sigma^{2} e\right)$

Where, $\left(\sigma^{2} \mathrm{e}\right)=$ error variance

\section{Genotypic and Phenotypic Coefficient of Variation (GCV and PCV)}

The genotypic and phenotypic coefficients of variation were calculated according to the formulae given by Falconer (1960).

Genotypic coefficient of variation (GCV)

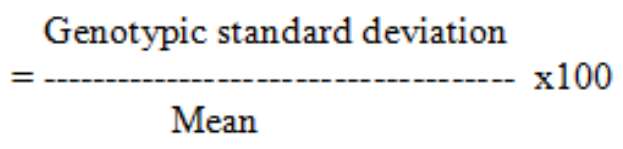

Phenotypic coefficient of variation (PCV)

Phenotypic standard deviation

Mean $\times 100$

Categorization of the range of variation was done as proposed by Sivasubramanian and Madhavamenon (1973).

Less than $10 \%$ : Low

10-20 \%: Moderate

More than $20 \%$ : High 


\section{Heritability $\left(h^{2}\right)$}

Heritability in the broad sense refers to the proportion of genotypic variance to the total observed variance in the total population. Heritability $\left(\mathrm{h}^{2}\right)$ in the broad sense was calculated according to the formula given by Allard (1960).

$h^{2}(b s)=\frac{\sigma^{2} g}{\sigma^{2} p}$

Where,

$\mathrm{h}^{2}(\mathrm{bs})=$ heritability in broad sense

$\sigma^{2} \mathrm{~g}=$ genotypic variance

$\sigma^{2} p=$ phenotypic variance $\left(\sigma^{2} g+\sigma^{2} e\right)$

$\sigma^{2} \mathrm{e}=$ environmental variance

As suggested by Johnson et al., (1955) $\left(\mathrm{h}^{2}\right)$ estimates were categorized as:

Low : 0-30 \%

Medium : 30-60 \%

High : above $60 \%$

\section{Genetic Advance}

Genetic advance refers to the expected gain or improvement in the next generation by selecting superior individuals under certain amount of selection pressure. From the heritability estimates the genetic advance was estimated by the following formula given by Burton (1952).

$\mathrm{GA}=\sigma \mathrm{p} \cdot \mathrm{h}^{2}(\mathrm{~b}) . \mathrm{K}$

Where,

$\mathrm{GA}=$ Expected genetic advance
$\mathrm{K}=$ Selection differential, the value of which is 2.06 at $5 \%$ selection intensity

$\mathrm{h}^{2}(\mathrm{~b})=$ Heritability in broad sense

$\sigma p=$ Phenotypic standard deviation

Genetic advance as per cent of mean (GAM)

In order to visualize the relative utility of genetic advance among the characters, genetic advance as percent of mean was computed.

Genetic advance as percent of mean

$$
=\frac{\text { GA }}{\text { Grand mean }}
$$

The range of genetic advance as percent of mean was classified as suggested by Johnson et al., (1955)

Low : Less than $10 \%$

Moderate : $10-20 \%$

High : More than $20 \%$

\section{Results and Discussion}

The phenotypic and genotypic coefficients of variation did not vary widely in majority of the characters and most of them exhibited low to higher values indicating that sufficient amount of variability was available in the material and selection can be exercised whereas, low values were recorded for days to 50 per cent anthesis, days to 50 per cent silking, shelling percentage and tryptophan content. The PCV estimate for grain yield was maximum $(41.45 \%)$ followed by 100 kernel weight $(23.07 \%)$ and number of kernels per row $(23.02 \%)$. The PCV estimate was the lowest for days to maturity $(3.32 \%)$. The GCV estimate was maximum for grain yield 
(40.16\%) followed by number of kernels per row $(22.65 \%)$ and 100- kernel weight (20.90\%). The GCV estimate was the lowest for days to maturity $(3.03 \%)$. The ECV estimate was maximum for anthesis silking interval $(15.12 \%)$ followed by number of grain yield per plant $(10.26 \%)$ and 100kernel weight $(9.75 \%)$. The ECV estimate was the lowest for days to 50 per cent anthesis $(0.71 \%)$.

High PCV and GCV values were recorded for number of kernels per row, 100-kernel weight and grain yield whereas, anthesis silking interval, plant height, ear height, ear length, ear girth, number of kernel rows per ear, crude protein and lysine contents exhibited moderate values while, days to 50 per cent anthesis, days to 50 per cent silking, days to maturity, shelling percentage and tryptophan contents recorded low values (Table 1). It is evident from the table that PCV values were slightly higher than GCV values for all the characters under the study. A perusal of genetic parameters viz., phenotypic and genotypic coefficients of variation revealed less influence of environment on the characters under study. Therefore, response to direct selection may be effective in improving these traits. The results are in conformity with the findings of Tengan et al., (2012), Aminu and izge (2012), Elmyhum (2013), Mohan Lal and Dhirendra Singh (2014), Ogunniyan and Olakojo (2014), Ulganathan et al., (2015), Jaya Prakash et al., (2017) and Preeti Sharma et al.,(2017).

Majority of the characters exhibited higher heritability values in which ear height and ear girth recorded the highest values (99\%) followed by days to $50 \%$ anthesis $(98 \%)$, days to $50 \%$ silking $(97 \%)$ and number of kernels per row $(97 \%)$, ear length $(95.1 \%)$, grain yield (93.9\%), number of kernel rows per ear
(92.8\%), crude protein $(85 \%)$, days to maturity $(83.7 \%)$ and lysine (63\%). High heritability indicated that these characters were least effected by the environment and selection is effective for the improvement whereas, medium heritability values were recorded for anthesis silking interval (43\%), shelling percentage (47\%) and also for tryptophan $(53 \%)$. High genetic advance was recorded for plant height $(53.81 \%)$ and ear height $(24.59 \%)$; medium value was recorded for grain yield $(11.56 \%)$ while, low values were recorded for the remaining traits (Table 1 \& Figure 1 \&2). Genetic advance as per cent mean ranged from 2.49 for shelling percentage to 80.16 for grain yield with medium to higher values for the characters.

The traits, number of kernels per row, 100kernel weight and grain yield recorded high heritability coupled with high genetic advance indicating the preponderance of additive gene action where simple selection can be exercised in improvement of these traits whereas, days to 50 per cent anthesis, days to 50 per cent silking, days to maturity and lysine contents recorded high heritability coupled with low genetic advance indicating that these traits were under the control of non additive genes where heterosis breeding is rewarding for improvement of these traits. Medium heritability coupled with low genetic advance was recorded for anthesis silking interval and shelling percentage and tryptophan content revealing the preponderance of non additive genes and hence heterosis breeding is rewarding for the improvement of these traits. The results are in conformity with the findings Tengan et al., (2012), Elmyhum (2013), Mohan Lal and Dhirendra Singh (2014), Ogunniyan and Olakojo (2014), Ulganathan et al., (2015) Jaya Prakash et al., (2017) and Preeti Sharma et al., (2017). 
Table.1 Estimation of genetic parameters for sixteen characters in Quality protein maize

\begin{tabular}{|c|c|c|c|c|c|}
\hline Character & $\mathbf{P C V}$ & $\mathbf{G C V}$ & $\mathbf{E C V}$ & $\mathbf{h}^{\mathbf{2}} \mathbf{\text { bs }}(\mathbf{\%})$ & $\mathbf{G A M}$ \\
\hline Days to 50\% anthesis & 4.66 & 4.61 & 0.71 & 98 & 9.38 \\
\hline Days to 50\% silking & 4.57 & 4.50 & 0.76 & 97 & 9.13 \\
\hline Anthesis silking interval & 16.79 & 7.29 & 15.12 & 43 & 6.52 \\
\hline Days to maturity & 3.32 & 3.03 & 1.34 & 84 & 5.72 \\
\hline Plant height (cm) & 16.57 & 16.06 & 4.09 & 94 & 32.06 \\
\hline Ear height (cm) & 14.24 & 14.19 & 1.24 & 99 & 29.12 \\
\hline Ear girth (cm) & 18.40 & 18.35 & 1.34 & 99 & 37.70 \\
\hline Ear length (cm) & 17.54 & 17.10 & 3.89 & 95 & 34.35 \\
\hline Number of kernel rows per ear & 16.32 & 15.72 & 4.38 & 93 & 31.20 \\
\hline Number of kernels per row & 23.02 & 22.65 & 4.15 & 97 & 45.89 \\
\hline 100 kernel weight (g) & 23.07 & 20.90 & 9.75 & 82 & 39.03 \\
\hline Shelling percentage (\%) & 5.49 & 2.58 & 4.85 & 47 & 2.49 \\
\hline Crude protein content (\%) & 13.20 & 12.18 & 5.10 & 85 & 23.13 \\
\hline Tryptophan content (\%) & 8.70 & 6.33 & 5.96 & 53 & 9.49 \\
\hline Lysine content (\%) & 13.49 & 10.72 & 8.20 & 63 & 17.54 \\
\hline Grain yield (g/plant) & 41.45 & 40.16 & 10.26 & 94 & 80.16 \\
\hline
\end{tabular}

PCV: Phenotypic coefficient of variation; GCV: Genotypic coefficient of variation ECV: Environmental coefficient of variation; $h^{2}$ bs: Broad sense heritability GAM: Genetic advance as per cent mean at $5 \%$ level

Fig.1 Graphic representations of Phenotypic and Genotypic coefficients of variation for various characters in 31 quality protein maize genotypes

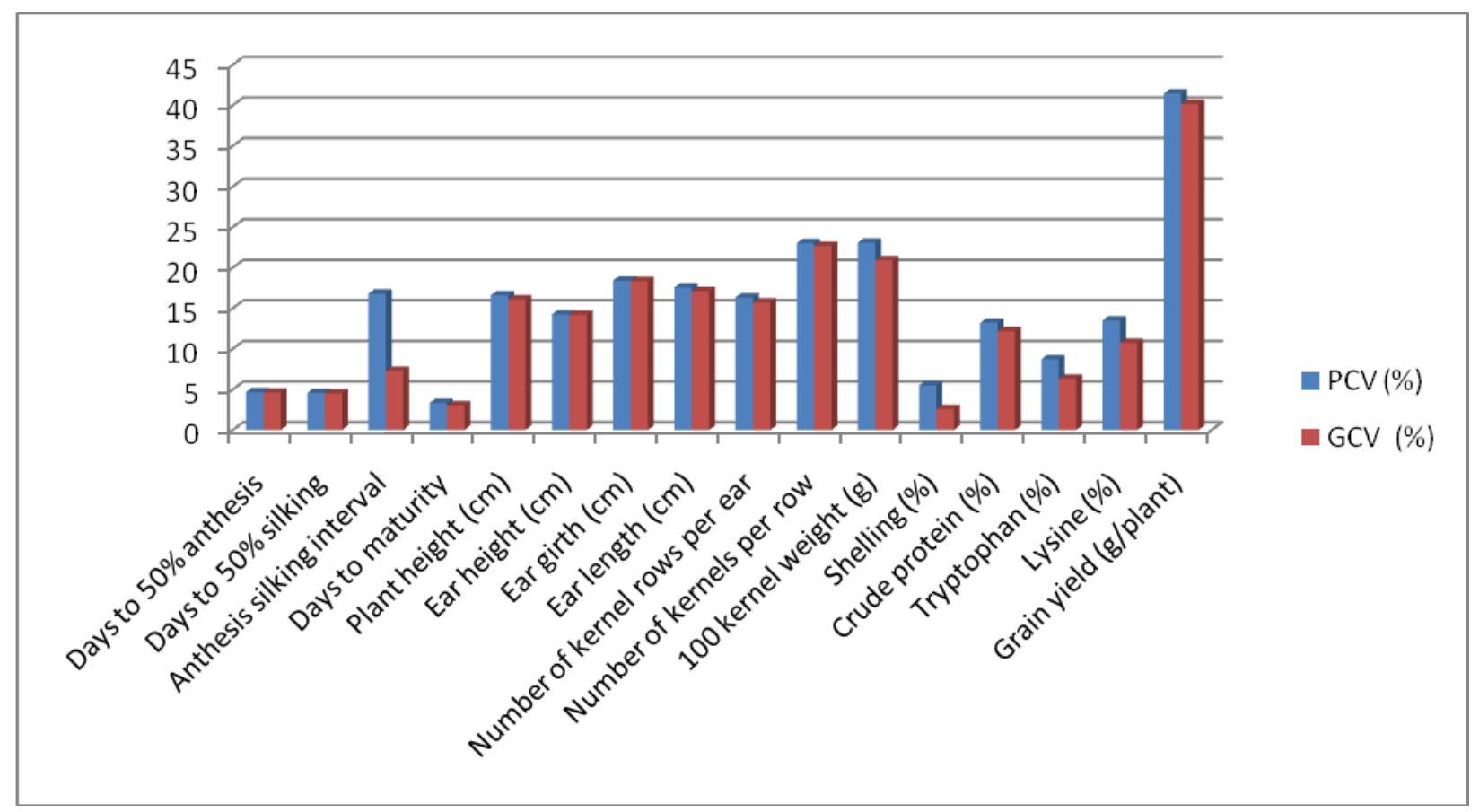


Fig.2 Graphic representations of heritability and genetic advance for 16 characters in 31 quality protein maize genotypes

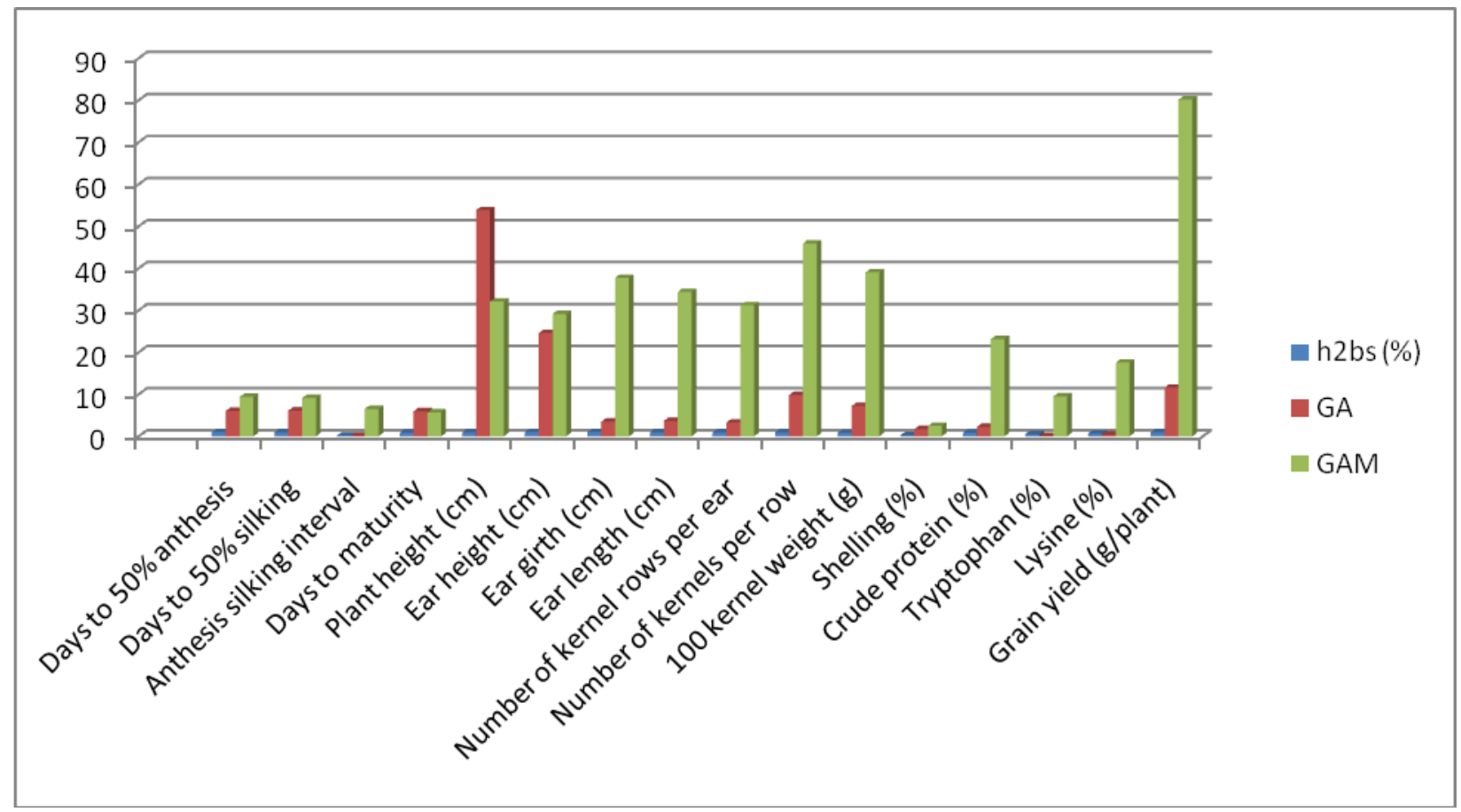

\section{References}

Aminu, D and Izge, A. U. 2012. Heritability and correlation estimates in Maize (Zea mays L.) under drought conditions in Northern Guinea and Sudan Savannas of Nigeria. World Journal of Agrcultutral Sciences. 8(6): 598-602.

Bilgin O, Korkut, K. Z., Baser, I., Dalioglu, O., Ozturk, I., Kahraman, T., Balkan,A.2010.Variation and heritability for some Semolina characteristics and grain yield and their relations in Durum wheat (Triticum durum Desf). World Journal of Agricultural Science. 6: 301-308.

Burton, G. W and Devane, E. M. 1953. Estimating heritability in fall Fescue (Festuca arundanaceae) from replicated coinal-material. Agronomy Journal. 45: 478-481.

Elmyhum, M., Dessalegn, T and Dessalegn, Y. 2013. Gene action and heterosis estimation in Quality Protein Maize. International Journal of Science and Research Publications. 3(6):1-17

Jay Prakash., Lata, S., Ankita sharma., Vekariya, R.D., Sharma, J.K and Ankita Sood. 2017. Evaluation of Quality Protein Maize (Zea mays L.) hybrids for quantitative and quality Traits. International Journal of Current Microbiology and Applied Sciences. 6(4): 1851-1859.

Johnson, H. W, Robinson, H. F and Comstock, R. E.1955. Estimates of genetic and environmental variability in Soybeans. Agronomy Journal. 47: 314-318.

Mohan Lal and Dhirendra Singh. 2014. Studies of variability using morphological and quality traits in Quality Protein Maize (Zea mays L.). Electronic Journal of Plant Breeding. 5(3): 526- 530.

Ogunniyan, D. J and Olakojo, S. A. 2014. Genetic variation, heritability, genetic 
advance and agronomic character association of yellow elite inbred lines of maize (Zea mays L.). Nigerian Journal of Genetics. 28: 24-28.

Panse, V. G. 1957. Genetics of quantitative characters in relation to plant breeding. Indian Journal of Genetics and Plant Breeding. 17: 318-328.

Panse, V. G and Sukhatme, P. V. 1985. Statistical methods for Agricultural workers, Indian Council of Agricultural Research, New Delhi.

Preeti Sharma, Punia, M. S., Kamboj, M. C., Narender Singh and Mehar Chand. 2017. Evaluation of quality protein maize crosses through line $\mathrm{x}$ tester analysis for grain yield and quality traits. Agricultural Science Digest. 37
(1): 42-45.

Siva Subramanian, S and Madhava Menon. 1973. Heterosis and Inbreeding depression in Rice. Madras Agricultural Journal. 60: 1339.

Ulganathan, Ibrahim, V. S. M., Gomathinayagam, P and Gurusamy, A. 2015. Genotype x Environmental interaction and stability for yield and its components in elite Maize types under moisture stress conditions. SABRAO Journal of Breeding and Genetics. 47(4): 355-365.

Wang, S. and Lu, Z. 2006. Genetic diversity among parental lines of Indica hybrid rice (Oryza sativa L.) in China based on coefficient of parentage. Plant Breeding. 125(6): 606-612.

\section{How to cite this article:}

Sukumar, K., V. Hemalatha, V. Narsimha Reddy, S. Narender Reddy and Srinivasa Chary, D. 2020. Genetic Variability, Heritability and Genetic Advance Estimates in Quality Protein Maize (Zea mays L.). Int.J.Curr.Microbiol.App.Sci. 9(07): 4008-4014. doi: https://doi.org/10.20546/ijcmas.2020.907.462 